\title{
Local Shortening of Folds and Detachment Surface Depth with Examples from the Foreland Belt of Iraq
}

\author{
Nabeel K. Al-Azzawi \\ Department of Geology \\ College of Science \\ Mosul University
}

(Received 24/9/2008, Accepted 26/3/2008)

\begin{abstract}
The percentage of local shortening of the Foreland Folds is quantified on the basis of simple geological trend and calculations of appropriate mathematical approaches.

The quantification method includes the measurements of the amount of the tectonic uplift of a measurement datum as well as, the amount of the entire uplifted mass represented in cross section by the area of the structural relief.

The application of the present method at two separate areas of the Foreland Belt of Iraq was lead to encouraging results and confidence in uses for tectonic analysis. The obtained results comply with the tectonic concepts of the area, and in the mean time it is compatible with other relevant studies.

$$
\begin{aligned}
& \text { التقصير الموضعي للطيات وعمق سطح الانفصال مع أمثلة من نطاق } \\
& \text { طيات الفورلاند في العراق } \\
& \text { نبيل قادر العزاوي } \\
& \text { قسم علوم الارض } \\
& \text { كلية العلوم } \\
& \text { جامعة الموصل }
\end{aligned}
$$

الملخص

تم حساب النسبة المئوية للتقصير الموضعي لطيات نطاق الفورلاند اعتماداً على الدفاهيم الجيولوجية وتطبيق طرق رياضية مناسبة. هذه الطريقة الكمية تتضمن قياسات لمقدار الرفع التكتوني من مستوي القياس المرجعي والكمية الكليةالمرفوعة والممتلة بالمقطع العرضي بمساحة الارتفاع التركيبي. إن تطبيق هذه الطريقة على منطقتين من نطاق الفورلاند العراقي، اعطى نتائج مشجعة باستخدامها في التحليل النكتوني في هذا النطاق، وان النتائج المستحصلة قد نكاملت مع النظرة النكتونية للمنطقة وكانت منوافقة مع الدراسات الممانلة.
\end{abstract}




\section{INTRODUCTION}

The most common technique used for measuring the amount of shortening is the balancing cross section. The construction of this method has led to many types of geometric constraints and it made many dilemmas to geologists during its practical applications. Many authors have dealt with balanced cross sections like Bally et al. (1966), Dahlstrom, (1969 and 1970) and Elliot and Boyer (1982) in Ramsay and Huber (1987) and Suppe (1985). It can be used for balancing or checking the reliability of the constructed cross sections along regional scale and determining the depths of detachment surfaces as well as calculating the amount of shortening.

Suppe (1985) considered this method as Retrodeformation with fundamental assumptions like conservation of mass, volume and bed length. He also defined some terms to explain the procedure of this method. Such terms are the curvimetric shortening $S c$ and planimetric shortening $S a$ which deal with lengths and areas respectively.

The present study suggests this simple mathematical technique to determine the amount of local shortening with the addition of a new factor (additional tectonic uplift) that influencing the amount of shortening. This technique is capable to determine the shortening of the entire anticline structure as well as the regional shortening; when a regional section is divided into successive parts (anticlines, synclines and may be horizontal or subhorizontal strata). The important practical advantage of this technique is to avoid the complexity of the balance cross section method when it is used merely for determining the amount of shortening and the depth of the detachment surface.

\section{THE SHORTENING AND DETACHMENT SURFACE}

The determination of the amount of shortening of any fold (anticline or syncline) depends on the amount of the total mass which was uplifted (in the anticline case) or subsided (in syncline) during rock folding. The measurements can be taken along a cross sectional area of an anticline or syncline between two inflections points. These two points, and for the sake of the application can be replaced by two exposure points of the same strata that have the same stratigraphic positions (Al-Azzawi, 2003). The cross sectional area $A F$ in figure (1A) represents the pre- deformational cross sectional area of the formations which are horizontally bounded between $L i \& R i$ which represent the exposure points of the measurement datum (will be mentioned here after) and vertically between this datum and the detachment surface. Whereas $A B$ in figure (1B) corresponds to the bulk post-deformation cross sectional area of the anticline and $A R$ stands for the area of the uplifted mass.

Then the amount of shortening in this anticline can be calculated as follow:

$$
\text { Amount of shortening }=(\boldsymbol{L c}-\boldsymbol{L o}) / \boldsymbol{L o} \ldots \ldots . . \text { Ramsay }(1967)
$$

Where $L c$ is the deformed length of conserved bed and $L o$ is its original length.

The percentage of shortening of any anticline $=\boldsymbol{A R} . \mathbf{1 0 0} / \boldsymbol{A F}$

$$
\boldsymbol{S c}=\boldsymbol{L c}-\mathbf{L o} \ldots . . \text { Suppe }(1985)
$$

Where $S c$ is the Curvimetric Shortening.

$$
\boldsymbol{A s r}=\boldsymbol{S c} . \boldsymbol{h} \ldots \ldots \text { Suppe(1985) and Ramsay and Huber (1987) }
$$




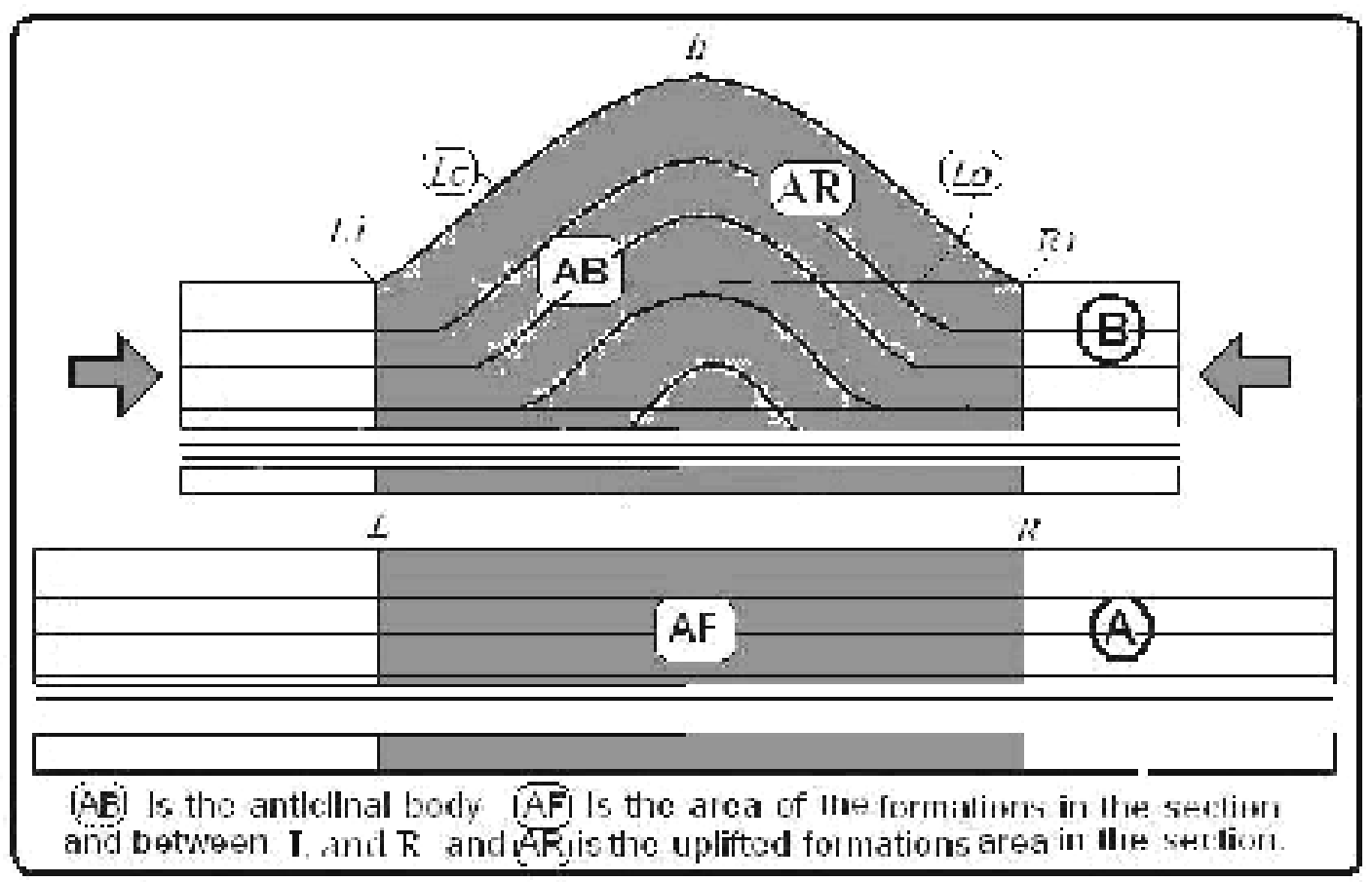

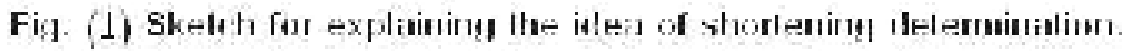

Where Asr is the area of structural relief whereas $h$ refers either to the depth of the detachment surface or the bottom of the listric fault that influenced the anticline. In this work $h$ is related to the first consideration.

The deformation uplifted the rock mass above the datum that joining the exposure points. This mass was called in cross section the area of structural relief Asr. In the case of a fold shortening, another factor must be taken into consideration when the amount of shortening is determined. It is the additional amount of tectonic uplift $T u$ that elevated the measurement datum from its original stratigraphic position and made an additional uplifted area $T a$ (Fig.2). In the case of a syncline, it may be called tectonic subsidence. Consequently, the area $A R$ will comprise both areas $A s r$ and $T a$.

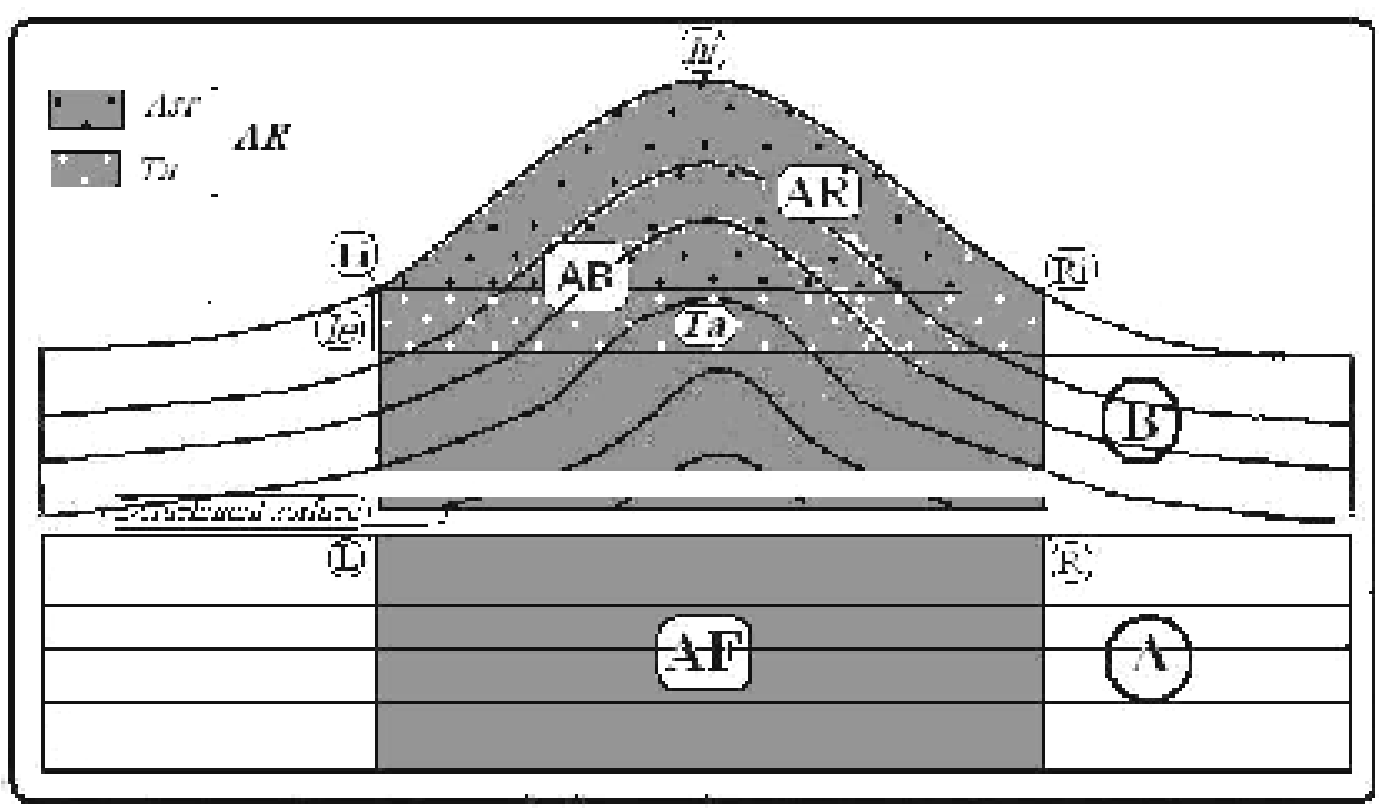

Fig. (2) siketch for explaining the effoct of Iectonic upliti. 
In the Foreland Belt of Iraq, the folds are manifested by the Pliocene paroxysmal phase of the Alpine Orogeny (Numan and Al-Azzawi, 2002; Al-Azzawi, 2003; Jassim and Goff, 2006; Al-Adeeb, 2007). Thus Mukdadiya and Bai Hassan Formations have been deposited when folding was growing up whereas Injana formation was completely deposited before the beginning of the paroxysmal stage of folding. For this reason, the upper surface of Injana formation, in the present work, is taken as the datum of measurements. Since the Injana Formation was deposited in a fluvial environment (Jassim and Goff, 2006). Then the elevation of top of this formation can be assumed as equivalent to sea level at that time. And because there is no an eustatic difference between the Late Miocene sea level and that of the present day (Sharland et al, 2001), the additional tectonic uplift can be equivalent to the present day elevation of the top of the Injana Formation, here called Injana Elevation (Ie) (Fig.2). However, it must be mentioned that the deformation led to an increase in weight of the deformed rocks so that it caused isostatic subsidence. On other hand, there is a latteraly isostatic uplift due to the effect of the eroded mass of the studied anticline. Surely, the isostatic subsidence was more than that of uplift. But for simplifying the procedure of this technique, it is assumed that this isostatic subsidence can equilibrate the isostatic uplift.

So that,

$$
\mathrm{Ta}=\mathrm{Lo} . \mathrm{Ie}
$$

Where $T a$ is the area that created by the additional tectonic uplift and must be added to the area of the uplifted mass $A R$.

So,

$$
A R=A s r+T a
$$

Consequently, the percentage of shortening of any given anticline becomes:

$$
\text { Shortening\% }=(A s r+T a) .100 / A F
$$

\section{METHODOLGY}

In order to simplify the mathematical approach of this technique, each quarter wavelength QW of any fold is separately taken for determination. Therefore the anticline or syncline is divided into two parts. The first one represents the left hand side occupying the area bounded by the curve from the hinge hi to the left hand exposure point Li.

While the second part is the right hand side of this section from the hinge hi to the right exposure point $\mathrm{Ri}$ (Fig.2). Therefore, the determination of the area Asr must be individually applied on the first and second quarter wavelengths. The following steps explain the main procedure items:

\section{1st- The construction of fold profile:}

Constructing the fold profile or cross section is necessary if the data (strike directions and dip amounts) are available from a map. This construction is made by graphical Busk method (Busk ,1929 in Ramsay and Huber, 1978) or by mathematical techniques like that suggested by Al-Azzawi (2004) depending basically on the principles of Busk method (Fig. 2) and executed by a computer program "PROFILE.BAS".

\section{$2^{\text {nd }}$ - Determination of fold function:}

Fold function can be determined by applying the $X$ and $Y$ coordinate values of fold profile to the Least Squares or Lagrangian polynomial Interpolation methods. The theory 
of these methods is given by Gerald and Wheatly (1984). Al-Azzawi (2004) used these methods in analyzing the folds and, hence, utilized a full description about their applications with a computer program called "LEAST.BAS".

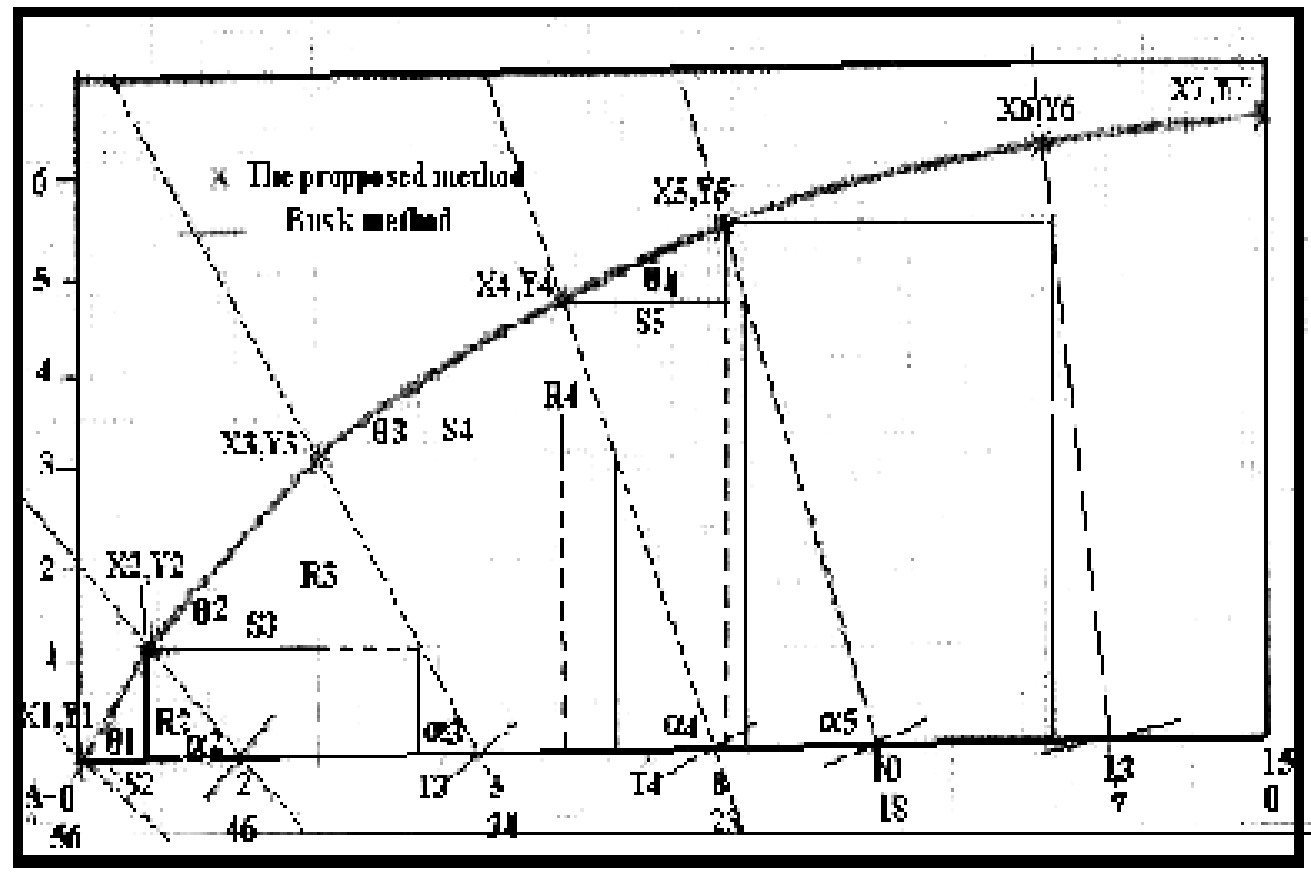

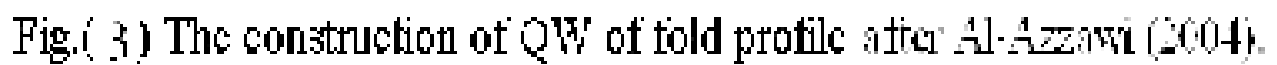

\section{$3^{\text {rd }}$ - Determination of the post-deformational cross sectional area:}

The cross sectional area of the quarter wavelength QW of a fold can be determined by a planimeter or mathematically by integration method. The latter is described by (Anton et al., 2002). This method is used to calculate the area bounded between two curves $f(x)$ and $g(x)$ on interval $[a, b]$, if $f(x) \geq g(x)$ for all $x$ in [a,b] (Fig. 4a). This means that the area of the QW is bounded above by $y=f(x)$, below by $y=g(x)$, the line $x=a$ on the left hand side, and $\mathrm{x}=\mathrm{b}$ on the right hand side (Anton et. al., 2002).

$$
\begin{array}{cccc}
b & & b & b \\
a & \int[f(x)-g(x)] d x & \text { OR } & A=\int f(x) d x \int g(x) d x \\
& & a & a
\end{array}
$$

Where $A$ is the cross sectional area of the $Q W$ of the fold.

Practically the curve representing fold profile can be bounded by selected coordinate frames so that the inflection point (or exposure point) of the curve is coincident with the origin point $(0,0)$ (Fig. $4 \mathrm{~b})$. Therefore, the lower boundary of the area becomes $y=0$ and $g(x)=0$.

$$
\text { b } b
$$

So

$$
A=\int_{0}^{b} f(x) d x \quad \text { or } \quad A s r=\int(\text { Fold Function }) d x
$$




\section{$4^{\text {th }}$ - Determination of amount of shortening:}

The uplifted and original cross sectional areas are respectively determined by the following equations:

$$
A R=A s r+T a \quad \text { and } A F=L o . h
$$

So that, the percentage of shortening can be calculated by this simple formula:

$$
\text { Shortening \%=AR. } 100 / A F
$$

\section{THE FIRST EXAMPLE}

This sample is taken from Qara Chauq North Anticline. The anticline is asymmetrical with axial surface dipping towards the northeast; double plunging and open fold (Fouad, 1983). The core of this anticline is Oligocene Group and covered by Euphrates, Fat'ha and Injana formations. The data of the cross section was taken from Fouad (1983).

From Figure (5), the following items can be found:

$L o=23.7 \mathrm{~cm}=5.925 \mathrm{Km} \quad$ Scale: $1: 25000$

$L c=27.1 \mathrm{~cm}=6.775 \mathrm{Km}$

Curvimetric Shortening $=L c-L o=0.85 \mathbf{K m}$

Therefore, the southwestern quarter wavelength (SW QW) function is:

$y 1=-0.00027 X^{4}+0.00191 X^{3}+0.00152 X^{2}+0.72 X-0.315$

The area of the SWQW $=\int_{0}^{11.9} y 1 d x=48.5 \mathrm{~cm}^{2}$

And, The northeastern quarter wavelength (NE QW) function is

$y 2=0.000025 X^{4}-0.004 X^{3}+0.0328 X^{2}+0.65 X+0.0161$

The area of the NE QW $=\int_{0}^{11.8} y 2 d x=45.1 \mathrm{~cm}^{2}$

Area of the structural relief $A s r=y 1+y 2$

$$
\begin{array}{ccc}
A s r=93.6 & \mathrm{~cm}^{2}=\mathbf{5 . 8 5}{\mathbf{~} \mathbf{m}^{2}}^{2} \\
A s r=S c . h & \text { So } h=A s r / S c \\
h=5.85 / 0.85 & \text { So } \quad \boldsymbol{h}=\mathbf{6 . 8 8} \mathbf{K m}
\end{array}
$$

This means that the depth of detachment surface is equal to $\underline{6.88} \mathbf{~ K m}$.

The area $A F$ which represent the cross sectional area of the bulk mass of the anticline beneath the exposed rocks, is calculated by multiplying the depth of the detachment surface by the original length of the bedding between $L i$ and $R i$.

$$
A F=L o . h \text { So } A F=5.925 * 6.88=40.76 \mathrm{Km}^{2}
$$

The additional tectonic uplift of the measurement datum $T u=$ Injana Elevation $I e=$ $0.3 \mathrm{Km}$.

$$
T a=I e . L o \quad \text { So } T a=0.3 \mathrm{Km} .5 .925 \mathrm{Km}=1.7775 \mathrm{Km}^{2}
$$

The cross sectional area of the uplifted mass that caused by the structuration and the tectonic uplift is:

$$
\boldsymbol{A R}=T a+A s r=1.7775+5.85=7.6275 \mathbf{K m} 2 .
$$

The anticline shortening $\%=A R .100 / A F=7.6275 .100 / 40.76=\underline{\mathbf{1 8 . 7} \%}$ 


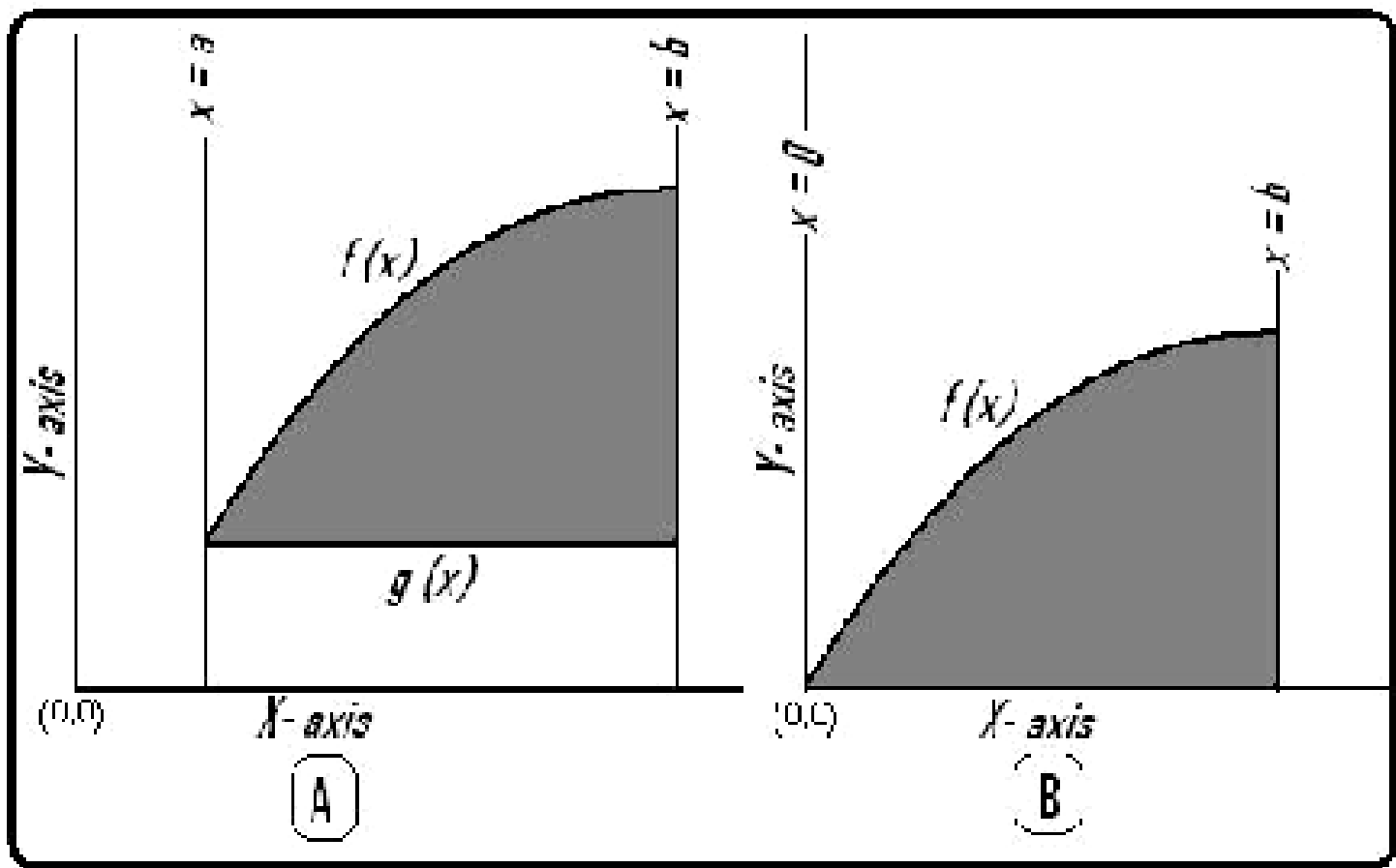

Fig. (4) The determined area and its functions and limits.

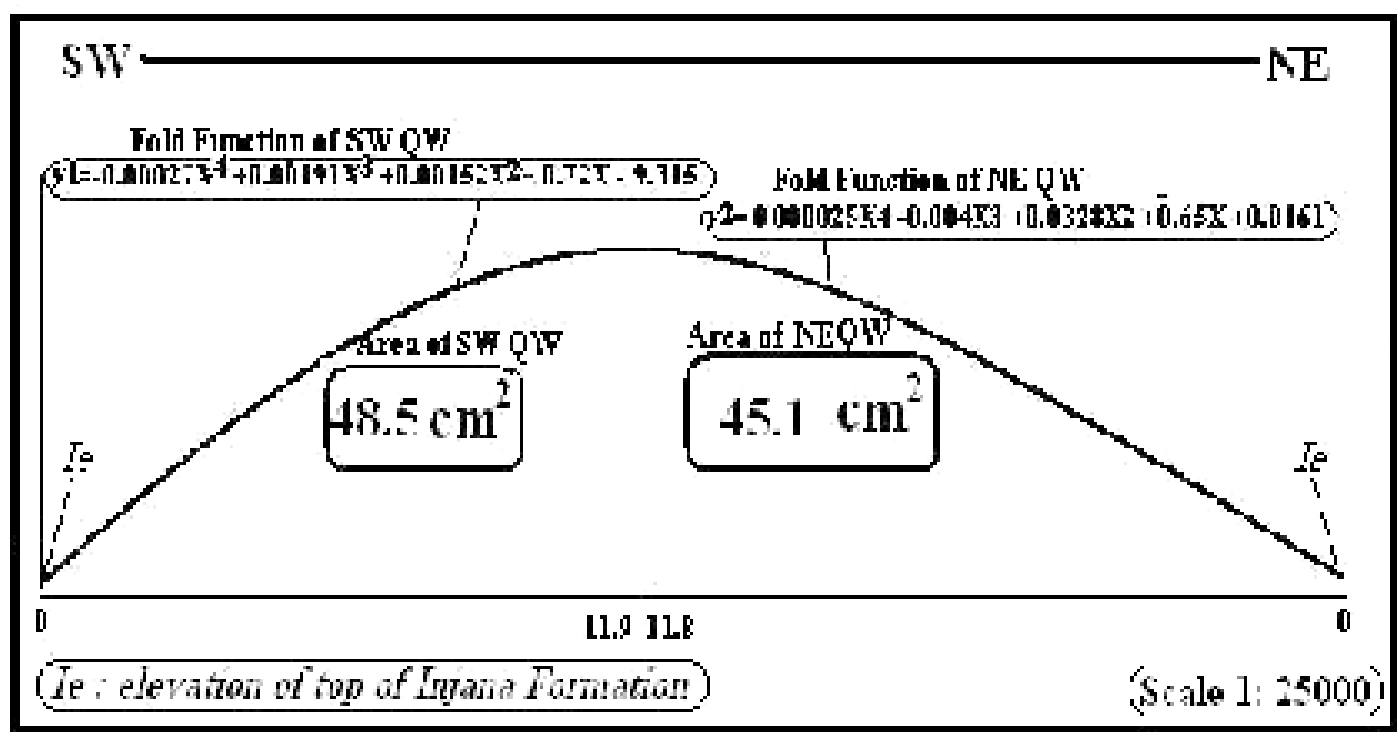

\section{Fig. (E) Detcrmination of the area of shuctenal relicf for Qara Cleuq sinticline}

\section{THE SECOND EXAMPLE}

Another test is applied to Bekhair Anticline. The southeastern plunge is located near Zawita Village and the anticline extends west- northwesterly through Dohuk city to Zakho and the Turkish-Syrian-Iraqi borders. Ameen (1979) and Al-Alawi (1980) described this anticline in detail. Bekhme and Shiranish formations are exposed in the area as the Upper Cretaceous formations whereas Kolosh, Gercus, Pila Spi, Fat'ha and Injana represent the Tertiary formations. 
The tested traverse is located between Baroshki and Ekmala Villages passing near Dohuk City, i.e from the southern to the northern limbs of Bekhair Anticline. Measurements on this anticline are as follows:
$L o=43.8 \mathrm{~cm}=8.76 \mathrm{Km} \quad$ Scale $=1: 20000$
$L c=51.3 \mathrm{~cm}=10.26 \mathrm{~K}$

Curvimetric Shortening $=L c-L o=1.5 \mathrm{Km}$

Using the similar approach in the first example, the area of the structural relief can be determined as follows:

$$
\begin{gathered}
A s r=290.97 \mathrm{~cm}^{2}=11.6388 \mathbf{~ K m}^{2} \\
A s r=S c . h \quad \text { So } h=A s r / S c \\
h=11.6388 / 1.5 \quad \text { So } \quad h=7.76 \mathbf{~ K m}
\end{gathered}
$$

This means that the depth of detachment surface is equal to $7.76 \mathrm{Km}$.

The area $A F$ represents the cross sectional area of the bulk mass of the anticline beneath the exposed rocks, is calculated by multiplying the depth of the detachment surface by the original length of the bedding between $L i$ and $R i$.

$$
A F=L o . h \text { therefore } A F=8.76 * 7.76=67.98 \mathrm{Km}^{2}
$$

The additional tectonic uplift of the anticline $T u=$ Injana Elevation $I e=0.7 \mathrm{Km}$.

$$
T a=I e . L o \text { So } T a=0.7 \mathrm{Km} .8 .76 \mathrm{Km}=6.132 \mathrm{Km}^{2}
$$

Thus the cross sectional area of the uplifted mass that caused by the structuration and the tectonic uplift is:

$$
\begin{gathered}
A R=T a+A s r=6.132+11.6388=17.77 \mathbf{K m}^{2} . \\
\text { The anticline shortening } \%=A R .100 / A F=17.77 .100 / 67.98=\underline{\mathbf{2 6 . 1} \%}
\end{gathered}
$$

\section{CONCLUSIONS}

The simple mathematical method applied in this work for the determination of the depth of detachment surface and percentage of local shortening of a certain anticline, is controlled by two factors. The first one is the amount of uplifted mass due to the structuration represented in a cross section by the area of structural relief Asr. The second factor is the amount of uplifting of the measurement datum from its original stratigraphic position $T a$. Here, it refers to the uplifting of the upper surface of Injana Formation Ie which is considered as the measurement datum. And it must be mentioned that the selection of this measurement datum is very important because a different measurement datum gives different results.

Empirically, the technique of measuring the local shortening of an anticline yields encouraging results as to the amount of shortening and the depth of the detachment surface. The determined amounts of shortening for Qara Chauq and Bekhair Anticlines are $18 . \vee \%$ and $26.1 \%$ respectively. These values are reliable but they seem to be higher than that determined in previous works. This is because the present work deals with the local shortening of a single fold, whereas previous works determined the regional shortening comprising the high and low deformed strata (anticline, syncline and some time horizontal or subhorizontal strata). Al-Shali (1992) determined the regional amount of shortenings along four traverses. These are 5\%,8\%, 7\% and 12\% for Sulimaniya, Shaqlawa, Dohuk and Zakho traverses. The present results seem to be of higher values 
because they are related to rather highly deformed anticlines comparing with the surrounding areas. So naturally, the local shortening values become higher than that of the regional shortening.

The depth of the detachment surface was calculated in Qara Chauq and Bekhair Anticlines. They are $6.8^{\wedge} \mathrm{Km}$ and $7.7^{\top} \mathrm{Km}$ respectively. These values are reliable when they are correlated with the estimated values of the previous studies of the Foreland of Iraq.

Al-Berifkani (personal communication) calculated the depth of the basement around Zakho area (not far from Bekhair Anticline). It is around $7.5 \mathrm{Km}$. Here, one important question arises. Are these values related to the depth of the detachment surface or depths of the crystalline basement? Suppe (1985) defined these values $(h)$ as the depth of undeformed strata. It means that the depth of a surface of the deformed strata was detached from undeformed one. Consequently, it may be concluded that the detachment surface may coincide with the crystalline basement at least beneath Bekhair Anticline.

Baikher Anticline is located to the northwest of Qara Chauq Anticline. Then the values $6.8^{\wedge} \mathrm{Km}$ and $7.7^{\nearrow} \mathrm{Km}$ indicate that the detachment surface is apparently inclined toward the northwest with gradient equal to $8 \mathrm{~mm} / \mathrm{m}$ or about $1^{\circ}$. This northwestwards inclination is an apparent dip whereas the true dip is known to be towards the north in the western part of the Foreland Belt and towards the northeast in its eastern part. Sharland et al (2001) stated that "The Arabian plate was progressively tilting toward the northeast". Nevertheless Al -Daoodi (1989) suggested that the crystalline basement becomes deepest toward the east and southeast. So this may suggest either that the detachment surface is coincident with the basement surface beneath Bekhair Anticline and not in other places, or this surface is coincident with the basement as a whole. This can be solved if the analysis comprises 10 or more anticline in the Foreland Belt, and this is recommended in the present work.

\section{REFRENCES}

Al-Adeeb, H.G., 2007. Tectonics of Molasse Basin, Unpub. Ph. D thesis, University of Mosul, Iraq.

Al-Alawi, M.N.T., 1980. Structural Geology of Bekhair Anticline - Northern Iraq, Unpub. M. Sc thesis, University of Mosul, Iraq.

Al-Azzawi, N.K.B., 2003. The Structural Development of Fold Shape in the Foreland Belt of Iraq. And Its Tectonic Implications, Unpublished $\mathrm{Ph}$. D Thesis, Univ. of Mosul, Iraq.

Al-Azzawi, N.K.B., 2004. Determination of Fold Profiles and Functions, a Mathematical Approach, Iraqi Jour. of Earth Science, Vol. 4, No. 1, pp 22-35.

Al-Daoodi Kh.A.H., 1989. Topographic and Tectonic Investigations of the Basement Rocks of the Simple Folds Zone - Northern Iraq, Unpub. M. Sc thesis, University of Mosul, Iraq.

Al-Shali, R.A., 1992. Balancing Cross sections from the Simple Folded Zone of Iraq, Unpublished M.Sc. Thesis, Univ. of Mosul, Iraq.

Ameen, M.S.,1979. Regional Investigation of Geoflexures and Tectonic Analysis in the Simple Folded Zone of Iraq, Unpublished M.Sc. Thesis, Univ. of Mosul. 
Anton, H., Bivens, I. And Davis, S., 2002. Calculus, Seventh Edition, John Wiley andSons INC., 1166P.

Fouad, S.F., 1983. Structural Geology of Qara Chauq Anticline, Unpublished M.Sc. Thesis, Univ. of Baghdad, Iraq.

Gerald, C.F. and Wheatley, P.O., 1984. Applied Numerical Analysis, Addison-Wesley Publishing Company, 3 th ed., 579p.

Jassim S.Z. and J. C. Goff, 2006. Geology of Iraq, Dolin, Prague and Moravian Museum, Brno, Czech Republic, 341p.

Numan, N.M.S., and Al-Azzawi, N. K. B., 2002. Progressive Versus Paroxysmal Alpine Folding in Sinjar Anticline Northern Iraq, Iraqi jour. of Earth Science, Vol. 2, No. 2, pp59-69.

Ramsay, J.G., 1967. Folding and Fracturing of Rocks, McGraw Hill, New York, 568p.

Ramsay, J.G., and Huber, M. I., 1987. The Techniques of Modern Structural Geology: V.2, Folds and Fractures, Academic Press, London, UK, 700p.

Sharland, P.R., Archer, R., Casey, D. M., Davies, R. B., Hall, S. H., Heward, A. P., Horbury, A.D. and Simmons, M.D., 2001. Arabian Plate Sequence Stratigraphy, GeoArabia special publication 2, 317P.

Suppe, J., 1985. Principles of Structural Geology, Prentice Hall International, Inc., London, 537p. 